\title{
Role of per-operative milrinone on pulmonary hypertension having mitral valve replacement.
}

1. MBBS, FCPS (Cardiac Surgery) Associate Professor Cardiac Surgery

Faisalabad Institute of Cardiology, Faisalabad.

2. B.Sc, MBBS

Resident MS Cardiac Surgery

Faisalabad Institute of Cardiology,

Faisalabad.

3. MBBS, MCPS (Medicine),

FCPS (Cardiology)

Associate Professor Cardiology

Faisalabad Institute of Cardiology,

Faisalabad.

Correspondence Address:

Dr. Shahbaz Ahmad Khilji

Associate Professor Cardiac Surgery

Faisalabad Institute of Cardiology,

Faisalabad.

drshahbazkhilji@gmail.com

Article received on:

03/09/2020

Accepted for publication:

03/12/2020

\section{Shahbaz Ahmad Khilji ${ }^{1}$, Shuja Tahir ${ }^{2}$, Shahid Abbas ${ }^{3}$}

ABSTRACT... Objective: To determine the role of perioperative milrinone on pulmonary hypertension in patients with mitral valve disease undergoing mitral valve replacement surgery. Study Design: Randomized Control Trial. Setting: Department of Cardiac Surgery, Faisalabad Institute of Cardiology, Faisalabad. Period: 10-10-2018 to 10-10-2019. Material \& Methods: A total of 80 patients with mitral valve disease who underwent mitral valve replacement were included. The patients were divided into a control group of 40 , who were not administered milrinone, and a study group of 40 who received milrinone perioperatively. TVPG, LVEF and NYHA class were recorded preoperatively and postoperatively and were compared. Results: In the study group, postoperative LVEFs and NYHA class were not statistically significant in both groups while postoperative TVPG was significantly lower in study group as compare to control group and is statistically significant $(P<0.001)$. Conclusion: Our study concludes that milrinone can be used as an effective therapy to reduce pulmonary pressure in patients with pulmonary hypertension undergoing mitral valve replacement surgery.

Key words: Left Ventricular Ejection Fraction, Mitral Valve Disease, Mitral Valve Replacement, Pulmonary Hypertension, Right Ventricular Failure.

Article Citation: Khilji SA, Tahir S, Abbas S. Role of per-operative milrinone on pulmonary hypertension having mitral valve replacement. Professional Med J 2021; 28(1):120-124. https://doi.org/10.29309/TPMJ/2021.28.01.6249

\section{INTRODUCTION}

Pulmonary hypertension $(\mathrm{PH})$ is characterized by increase in pulmonary vascular resistance leading to right ventricular failure. ${ }^{1}$ The most common cause of pulmonary hypertension worldwide is left heart disease ${ }^{2}$ amongst which valvular heart disease is the leading cause of secondary pulmonary hypertension. ${ }^{3}$ Patients with symptomatic mitral valve disease are severely affected by pulmonary hypertension and upto $65 \%$ of patients with symptomatic mitral stenosis ${ }^{4,5}$ have increased risk of morbidity and mortality during mitral valve replacement (MVR). ${ }^{6}$ Mitral stenosis results in increase in left atrial pressures causing reversible increase in pulmonary arterial pressures ${ }^{7}$ Immediately after MVR, pulmonary arterial pressure does not usually regress completely and persist in about $75 \%$ of patients having pre-operation severe pulmonary hypertension ${ }^{8}$ Milrinone is a phosphodiesterase inhibitor which is commonly used in such patients during weaning from cardiopulmonary bypass, to reduce the pulmonary vascular resistance ${ }^{9}$ Milrinone reduces biventricular filling pressures and afterload by systemic and pulmonary vasodilation. ${ }^{10,11,12}$ with no significant effect on patients heart rate ${ }^{13}$ The aim of this study is to determine the effect of perioperative milrinone on postoperative pulmonary hypertension after mitral valve replacement surgery.

\section{MATERIAL \& METHODS}

This Randomized control trial was conducted at Cardiac Surgery Department, Faisalabad Institute of Cardiology for One year from October 2018 to October 2019.

The sample size was colculated By using WHO sample size calculator

$$
n=\frac{Z \sigma^{2}\left(Z_{1-\alpha / 2}+Z_{1-\beta}\right)^{2}}{\left(\mu_{1}-\mu_{2}\right)^{2}}
$$

$\mu_{1}=41.25$

$\mu_{2}=44$ 
$a=5 \%$

$1-\beta=80 \%$

$\sigma=4.24$

Sample size $n=80$ (40 in each group)

\section{SAMPLE SELECTION}

\section{Inclusion Criteria}

- Patients of both gender and age.

- Patient with isolated mitral stenosis.

- Rheumatic mixed lesion with predominant mitral stenosis.

- Patients with moderate to severe pulmonary hypertension $(>30 \mathrm{mmHg})$.

\section{Exclusion Criteria}

- Patients with Right heart failure.

- Patients with moribund preoperative state.

- Patients having endocarditis and concomitant aortic valve disease.

- Patients with coronary artery disease, EF $<45 \%$.

- Patients with previous cardiac surgery.

- Patients with preoperative multi-organ disease.

After institutional ethical review committee approval informed consent was taken. 80 patients were enrolled who were scheduled for mitral valve replacement with severe pulmonary hypertension having tricuspid valve pressure gradient greater than $30 \mathrm{~mm}$ of hg on preoperative transthoracic echo were admitted through out-patient department. Clinical examination was done to confirm the diagnosis. Preoperative investigation was carried out in the ward. Two groups were formed depending upon milrinone administration. 40 patients who received milrinone were included in study group while 40 patients who did not were in control group. Postoperative TVPG, LVEF and NYHA class were recorded.

\section{SURGICAL TECHNIQUE}

Mitral valve replacement was done through median sternotomy. After aortic and bicaval venous cannulation cardiopulmonary bypass was established. Cold cardioplegia administered for myocardial protection and heart to stop. After left atrial atriotomy mitral valve excised with or without preservation of posterior mitral leaflet and is replaced with mechanical or tissue valve according to patient's condition. 40 patients received milrinone during weaning from cardiopulmonary bypass with loading dose of $25 \mu \mathrm{g} / \mathrm{kg}$. Maintenance dose was administered at dose of of $0.25 \mu \mathrm{g} / \mathrm{kg} / \mathrm{min}$ for 24 hours postoperatively. Statistical analysis was done using IBM SPSS Statistics Version 26.

\section{RESULTS}

Mean age in control group was $39.50 \pm 10.806$ while in study group $41.38 \pm 13.511$. Male ratio in control group were $18(45 \%)$ in study group there were 11 (27.5\%) (Table-I). We noticed no significant difference between LVEF and TVPG preoperatively in both groups (Table-III). Postoperative data showed that TVPG was significantly lower in study group $(28.55 \pm 8.470)$ than in control group (43.35 \pm 15.019$)$ and this difference was highly statistically significant ( $p$-value <.0001) (Table-IV). There was no significant difference between two groups in terms of LVEF and NYHA class. However, $31(77.5 \%)$ patients in study group were having NYHA class I postoperatively while in control group there were $28(70 \%)$ (Table-II).

\begin{tabular}{|c|c|c|c|c|}
\hline \multicolumn{2}{|c|}{ Variable } & \multirow{2}{*}{$\begin{array}{c}\begin{array}{c}\text { Control } \\
\text { Group }\end{array} \\
39.5 \pm \\
10.806\end{array}$} & \multirow{2}{*}{$\begin{array}{c}\text { Study } \\
\text { Group }\end{array}$} & \multirow{2}{*}{$\begin{array}{c}\text { P-Value } \\
0.513\end{array}$} \\
\hline \multicolumn{2}{|c|}{$\begin{array}{l}\text { Age (MEAN } \pm \\
\text { SD) Years }\end{array}$} & & & \\
\hline $\begin{array}{l}\text { Male } \\
\text { Number (\% }\end{array}$ & Sex & $18(45 \%)$ & $11(27.5 \%)$ & 0.151 \\
\hline \multicolumn{2}{|l|}{ NYHA II } & $24(60 \%)$ & $25(62.5 \%)$ & \multirow{2}{*}{0.818} \\
\hline \multicolumn{2}{|l|}{ NYHA III } & \multicolumn{2}{|c|}{$16(40 \%)$} & \\
\hline \multicolumn{5}{|c|}{ Table-I. Preoperative Data } \\
\hline Variable & \multicolumn{2}{|c|}{$\begin{array}{l}\text { Control } \\
\text { Group }\end{array}$} & $\begin{array}{l}\text { Study } \\
\text { Group }\end{array}$ & P-Value \\
\hline NYHA I & \multicolumn{2}{|c|}{$28(70 \%)$} & $31(77.5 \%)$ & \multirow{2}{*}{0.446} \\
\hline NYHA II & \multicolumn{2}{|c|}{$12(30 \%)$} & $09(22.5 \%)$ & \\
\hline \multicolumn{5}{|c|}{ Table-II. Postoperative NYHA Class } \\
\hline Variable & \multicolumn{2}{|c|}{$\begin{array}{l}\text { Control } \\
\text { Group }\end{array}$} & Study Group & P-Value \\
\hline LVEF & \multicolumn{2}{|c|}{$58 \pm 5.038$} & $58.38 \pm 5.705$ & 0.756 \\
\hline TVPG & \multicolumn{2}{|c|}{$51.80 \pm 17.775$} & $49.08 \pm 18.798$ & 0.507 \\
\hline \multicolumn{5}{|c|}{ Table-III. Preoperative ECHO Data } \\
\hline
\end{tabular}




\begin{tabular}{|l|c|c|c|}
\hline Variable & $\begin{array}{c}\text { Control } \\
\text { Group }\end{array}$ & Study Group & P-Value \\
\hline LVEF & $59 \pm 3.616$ & $59.25 \pm 2.667$ & 0.726 \\
\hline TVPG & $43.35 \pm 15.019$ & $28.55 \pm 8.470$ & 0.0001 \\
\hline & Table-IV. Postoperative ECHO Data \\
\hline
\end{tabular}

\section{DISCUSSION}

This study demonstrated that perioperative milrinone usage in patients having pulmonary hypertension reduces postoperative tricuspid valve pressure gradient and improves NYHA class after mitral valve replacement.

Mitral valve disease commonly results in pulmonary hypertension, which is associated with poor prognosis during mitral valve replacement. ${ }^{14,15}$

Mitral valve disease cause increase in left atrial pressures because of increase in pulmonary vascular resistance which in turn causes alveolar stress and remodeling of pulmonary vasculature. ${ }^{16}$ As there are selective drugs for pulmonary vasculature, treatment of pulmonary hypertension has not been fully established. Different class of drugs, such as vasodilators, beta agonist or phosphodiesterase inhibitors were administered to reduce $\mathrm{PH}$ during cardiac surgery. ${ }^{17}$ However, arrythmias and increased demand of myocardial oxygen may occur because of these drugs which results in ischemia and renal failure. ${ }^{18}$

Milrinone is a phosphodiesterase-III inhibitor which increases the cAMP levels in cells by decreasing its degradation and activates protein kinase A3. Therefore, its cardiac effects are positive inotropy and improved diastolic relaxation. The effect of milrinone which is a potent vasodilator also causes reduction in preload, afterload, and pulmonary vascular resistance which helps in weaning from

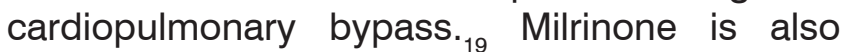
widely used in patients with heart failure as well as in congenital heart surgery. ${ }^{20,21}$

Some of the studies demonstrated the use of milrinone in patients with pulmonary hypertension undergoing mitral valve replacement. Ahmet et al reported that with the use of milrinone perioperatively, systolic pulmonary artery pressure and low cardiac output syndrome significantly reduces. ${ }^{9}$ Wang et al showed the reduction in mean pulmonary artery pressure and pulmonary vascular resistance with the use of milrinone. ${ }^{22}$ Some studies reported that by perioperative administration of milrinone which significantly reduces right and left ventricles filling pressures, causes reduction in pulmonary hypertension. ${ }^{19}$ In our study NYHA class and pulmonary hypertension improves with the use of milrinone in patients undergoing mitral valve replacement.

\section{CONCLUSION}

Perioperative administration of milrinone significantly reduces pulmonary hypertension and improves NYHA class after mitral valve replacement surgery.

Copyright $@ 03$ Dec, 2020.

\section{REFERENCES}

1. Shewale V, Jadhao M, Shah V, Raut C, Mishra P, Khandekar J. Patients with severe pulmonary artery hypertension undergoing mitral valve. 2020; 08(04):279-84.

2. Galiè N, Humbert M, Vachiery J-L, Gibbs S, Lang I, Torbicki A, et al. 2015 ESC/ERS Guidelines for the diagnosis and treatment of pulmonary hypertension: The Joint Task Force for the Diagnosis and Treatment of Pulmonary Hypertension of the European Society of Cardiology (ESC) and the European Respiratory Society (ERS): Endorsed by: Association for European Paediatric and Congenital Cardiology (AEPC), International Society for Heart and Lung Transplantation (ISHLT). Eur Heart J. 2016 Jan; 37(1):67-119.

3. Weitsman T, Weisz G, Farkash R, Klutstein M, Butnaru $A$, Rosenmann D, et al. Pulmonary hypertension with left heart disease: Prevalence, temporal shifts in etiologies and outcome. Am J Med. 2017 Nov; 130(11):1272-9.

4. Baumgartner H, Falk V, Bax JJ, De Bonis M, Hamm C, Holm PJ, et al. 2017 ESC/EACTS Guidelines for the management of valvular heart disease. Eur Heart J. 2017 Sep; 38(36):2739-91.

5. Villanueva DLE, Agustin RD, Llanes EJ. Pre-Operative sildenafil for patients with pulmonary hypertension undergoing mitral valve surgery: A systematic review and meta-analysis. Cardiol Res. 2019 Dec; 10(6):369-77. 
6. Bermejo J, Yotti R, García-Orta R, Sánchez-Fernández PL, Castaño M, Segovia-Cubero J, et al. Sildenafil for improving outcomes in patients with corrected valvular heart disease and persistent pulmonary hypertension: A multicenter, double-blind, randomized clinical trial. Eur Heart J. 2018 Apr; 39(15):1255-64.

7. Magne J, Pibarot P, Sengupta PP, Donal E, Rosenhek R, Lancellotti P. Pulmonary hypertension in valvular disease: A comprehensive review on pathophysiology to therapy from the HAVEC Group. JACC Cardiovasc Imaging. 2015 Jan; 8(1):83-99.

8. Barbash IM, Escarcega RO, Minha S, Ben-Dor I, Torguson R, Goldstein SA, et al. Prevalence and impact of pulmonary hypertension on patients with aortic stenosis who underwent transcatheter aortic valve replacement. Am J Cardiol. 2015 May; 115(10):143542.

9. Dolapoğlu A, Avcı E. Effect of peri-operative milrinone on pulmonary artery pressure in patients undergoing mitral valve replacement. J Surg Med. 2019; 3(10):71821.

10. Nguyen A, Holecko J, Essandoh M. Milrinone in adult cardiac surgery: More evidence is needed to support routine inhalation administration. J Cardiothorac Vasc Anesth [Internet]. 2019 Mar 1; 33(3):674-6. Available from: https://doi.org/10.1053/j.jvca.2018.10.015.

11. Essandoh MK. Afterload mismatch after mitraclip implantation: The potential impact of pharmacologic support. J Cardiothorac Vasc Anesth. 2017 Apr;31(2):702-6.

12. Tang GHL, Cohen M, Dutta T, Undemir C. Afterload mismatch after transcatheter mitral valve repair with MitraClip for degenerative mitral regurgitation in acute cardiogenic shock. Catheter Cardiovasc Interv [Internet]. 2018 Sep 1; 92(3):E168-71. Available from: https://doi.org/10.1002/ccd.27019.

13. Han B, Wang Q. Study on the clinical efficacy of specific phosphodiesterase inhibitor in patients with pulmonary hypertension due to left heart disease. Exp Ther Med [Internet]. 2018/06/13. 2018 Aug; 16(2):1175-86. Available from: https://pubmed.ncbi. nlm.nih.gov/30112056.

14. Alsancak $Y$, Gürbüz AS, Düzenli MA. Transcatheter mitral valve repair and replacement; current therapies and general evaluation of new approaches. Journal of Surgery and Medicine. 2017 Dec 10;1(3):56-8.
15. Ibrahim IM, Dokhan AL, Elsebaey RS, Abdellatif $M G$, Elsebaey RS, Abdellatif MG. Evaluation of the preoperative administration of sildenafil on operative and early postoperative outcome after mitral valve replacement in patients with pulmonary hypertension. Egypt Cardiothorac Surg [Internet]. 2020 Oct 1; 2 (4 SE-Adult cardiac):148-54. Available from: https://journals.escts.net/ects/article/view/150.

16. Maeder MT, Weber L, Buser M, Gerhard M, Haager PK, Maisano $F$, et al. Pulmonary Hypertension in Aortic and Mitral Valve Disease [Internet]. Vol. 5, Frontiers in Cardiovascular Medicine. 2018. p. 40. Available from: https://www.frontiersin.org/article/10.3389/fcvm. 2018.00040 .

17. Landoni G, Lomivorotov V V, Alvaro G, Lobreglio R, Pisano A, Guarracino $F$, et al. Levosimendan for hemodynamic support after cardiac surgery. $N$ Engl $J$ Med [Internet]. 2017 Mar 21; 376(21):2021-31. Available from: https://doi.org/10.1056/NEJMoa1616325.

18. Sardo S, Osawa EA, Finco G, Gomes Galas FRB, de Almeida JP, Cutuli SL, et al. Nitric oxide in cardiac surgery: A meta-analysis of randomized controlled trials. J Cardiothorac Vasc Anesth [Internet]. 2018 Dec 1; 32(6):2512-9. Available from: https://doi. org/10.1053/j.jvca. 2018.02.003.

19. Ushio M, Egi M, Wakabayashi J, Nishimura T, Miyatake $\mathrm{Y}$, Obata N, et al. Impact of milrinone administration in adult cardiac surgery patients: Updated metaanalysis. J Cardiothorac Vasc Anesth [Internet]. 2016 Dec 1;30(6):1454-60. Available from: https://doi. org/10.1053/j.jvca. 2016.07.027.

20. Burkhardt BEU, Rücker G, Stiller B. Prophylactic milrinone for the prevention of low cardiac output syndrome and mortality in children undergoing surgery for congenital heart disease. Cochrane database Syst Rev. 2015 Mar; (3):CD009515.

21. Hashim T, Sanam K, Revilla-Martinez M, Morgan CJ, Tallaj JA, Pamboukian S V, et al. Clinical characteristics and outcomes of intravenous inotropic therapy in advanced heart failure. Circ Heart Fail. 2015 Sep; 8(5):880-6.

22. Wang H, Gong M, Zhou B, Dai A. Comparison of inhaled and intravenous milrinone in patients with pulmonary hypertension undergoing mitral valve surgery. Adv Ther. 2009 Apr; 26(4):462-8. 


\title{
Fear is a reaction. Courage is a decision.
}

\author{
"Sir Winston Churchill"
}

\section{AUTHORSHIP AND CONTRIBUTION DECLARATION}

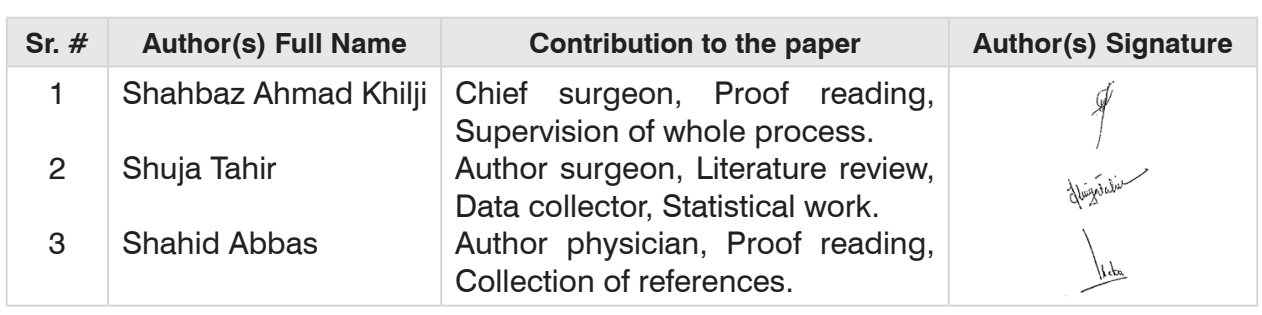

